\title{
THE ELECTROCHEMICAL BEHAVIOUR OF STAINLESS STEELS FOLLOWING SURFACE MODIFICATION IN CERIUM- CONTAINING SOLUTIONS
}

\author{
C. B. BRESLIN, ${ }^{*}$ C. CHEN $\dagger$ and F. MANSFELD $\dagger$ \\ * Department of Chemistry, St. Patrick's College Maynooth, Co. Kildare, Ireland \\ † Corrosion and Environmental Effects Laboratory (CEEL), Department of Materials Science and Engineering, \\ University of Southern California, Los Angeles, CA 90089-0241, U.S.A.
}

\begin{abstract}
The influence of cerium treatments on the anodic and cathodic polarisation behaviour of Type 316, 304 and 316L stainless steels is described. A decrease in the rate of the oxygen reduction reaction was observed on treating the stainless steels by immersion in cerium-containing solutions at elevated temperatures followed by polarization in the deep cathodic region. However, no inhibition of the oxygen reduction reaction was observed on simply treating the electrodes in the hot cerium-containing solutions. A more significant reduction in the rate of the cathodic reduction reaction was observed following the deposition of cerium oxides/hydroxide from ceriumcontaining solutions. This cathodic inhibition effect was found to diminish with continued immersion of the electrode in chloride-containing solutions. Reductions in the passive current densities, increases in the polarisation resistances and increases in the pitting potentials were observed for the stainless steels following treatment in boiling cerium solutions. Similar results were obtained on treating the electrodes in equivalent sodium-containing solutions. These apparent increases in the resistance to pitting attack were attributed to the dissolution of $\mathrm{MnS}$ inclusions during the boiling treatments giving rise to surfaces with lower population densities of pit nucleation sites. The reductions observed in the passive current densities were attributed to passivation by nitrate rather than anodic inhibition effects promoted by deposited cerium oxides/hydroxides. (C) 1997 Elsevier Science Ltd
\end{abstract}

Keywords: A. stainless steel, B. cerium, C. pitting corrosion, D. passive films.

\section{INTRODUCTION}

Surface modification, which involves altering only the surface layers of a material, is becoming increasingly important in the enhancement of the corrosion resistance of many materials. ${ }^{1}$ The advantage of this approach lies in the fact that the natural physical and mechanical properties of the material are retained, while the corrosion resistance is increased. However, many traditional methods of surface modification involve the use of hexavalent chromium, a substance which is now recognized as both highly toxic and carcinogenic. Successful applications of environmentally acceptable alternatives have been limited, but recent studies ${ }^{2-13}$ have identified cerium species as possible replacements for the well-know chromium (VI) species.

The methods by which cerium has been incorporated into, or deposited onto, surfaces range from ion implantations, ${ }^{13}$ immersion of the electrodes in cerium-containing solutions at room temperatures, and at elevated temperatures, ${ }^{14-16}$ to the electroplating of cerium from solution. ${ }^{13,14}$ Corrosion inhibition by cerium is generally associated with a reduction in 
the rate of the cathodic reduction reactions. This has been shown for zinc, ${ }^{3}$ coppercontaining aluminium alloys ${ }^{4-12}$ and stainless steels. ${ }^{13-16}$ Indeed, the enhanced resistance to the onset of crevice corrosion of cerium-treated stainless steel observed by Lu and Ives ${ }^{14-16}$ has been explained in terms of a reduction in the rate of the oxygen reduction reaction following the cerium treatment. The observed inhibition of the cathodic reduction reaction has been attributed to the formation and precipitation of cerium oxides or hydroxides over cathodic sites, giving rise to a blocking effect. ${ }^{5-16}$ This has been shown clearly for coppercontaining aluminium alloys, where cerium-rich insoluble films have been identified at copper intermetallic precipitates, these films precipitating from solution because of the local increase in alkalinity at the copper cathodic sites. ${ }^{7-9,11,12}$ However, the mechanism(s) by which cerium-enriched films or hydroxides are formed, particularly on passive stainless steels, is not clear.

In this work, the electrochemical behaviour of SS304, SS316 and SS316L following various cerium pre-treatment steps was studied in an effort to gain information on, and an insight into, the processes by which cerium can modify and alter the properties of the passive films formed on stainless steels.

\section{EXPERIMENTAL METHOD}

Test specimens were prepared from 304,316 and $316 \mathrm{~L}$ stainless steels provided in sheet form (SS316L) or rod form (SS304 and SS316). The electrodes provided in rod form were embedded in a two-component epoxy resin and the exposed surface, approximately $2.0 \mathrm{~cm}^{2}$ in area, was polished mechanically with successively finer grades of $\mathrm{SiC}$ paper and 0.05 micron alumina powder to a mirror finish. The electrodes provided in sheet form were polished to a 1000 grit finish with $\mathrm{SiC}$ paper and a total area of $18 \mathrm{~cm}^{2}$ was exposed to the test solution. The variations in the surface preparation of the sheet and rod electrodes did not give rise to any observable differences in the electrochemical behaviour of the electrodes.

Following sample preparation the electrodes were treated in cerium salt solutions. This procedure involved immersing the electrodes in $0.05 \mathrm{~mol} \mathrm{dm}^{-3} \mathrm{Ce}\left(\mathrm{NO}_{3}\right)_{3}, 0.01 \mathrm{~mol} \mathrm{dm}^{-3}$ $\mathrm{CeCl}_{3}$ or $0.004 \mathrm{~mol} \mathrm{dm}^{-3} \mathrm{Ce}\left(\mathrm{CH}_{3} \mathrm{CO}_{2}\right)_{3}$ maintained at $90-95^{\circ} \mathrm{C}$ for periods ranging between 60 and $120 \mathrm{~min}$. These solutions were chosen because of their previous successful application in the surface modification of commercial aluminium alloys. ${ }^{7-9}$ Alternatively, small amounts of cerium were deposited onto the stainless steel electrodes from a $0.05 \mathrm{~mol} \mathrm{dm}{ }^{-3} \mathrm{Ce}\left(\mathrm{NO}_{3}\right)_{3}$ solution at room temperature at a cathodic current density of $10 \mu \mathrm{A} \mathrm{cm}^{-2}$ for a $10 \mathrm{~min}$ or $20 \mathrm{~min}$ period. Additional tests involved treating the electrodes under similar conditions in non-cerium containing solutions, namely in $0.15 \mathrm{~mol} \mathrm{dm}^{-3}$ $\mathrm{NaNO}_{3}, 0.03 \mathrm{~mol} \mathrm{dm}^{-3} \mathrm{NaCl}$, or $0.012 \mathrm{~mol} \mathrm{dm}^{-3} \mathrm{CH}_{3} \mathrm{CO}_{2} \mathrm{Na}$ solutions maintained at 90 $95^{\circ} \mathrm{C}$ for $60-120 \mathrm{~min}$.

A saturated calomel electrode (SCE) was used as the reference electrode and graphite rods were used as the auxiliary electrodes in a three-electrode glass cell. A $0.6 \mathrm{~mol} \mathrm{\textrm {dm } ^ { - 3 }}$ $\mathrm{NaCl}$ solution containing $0.1 \mathrm{~mol} \mathrm{dm}{ }^{-3} \mathrm{Na}_{2} \mathrm{SO}_{4}$, or a $0.1 \mathrm{~mol} \mathrm{dm}^{-3} \mathrm{NaCl}$ solution prepared from Analar-grade reagents and de-ionized water were used as test electrolytes.

Electrochemical polarization tests were carried out using a PAR Model 273 potentiostat controlled by PAR Model 352 corrosion software. In potentiodynamic polarization tests the working electrodes were immersed in the test solution for $30 \mathrm{~min}$ and then polarized from the open-circuit potential at a rate of $0.18 \mathrm{mV} \mathrm{s}^{-1}$ either in the anodic direction up to 
the pitting potential, or in the cathodic direction. In tests, where the electrodes were polarized at cathodic potentials prior to recording the polarization curves, the electrodes were maintained at $-1500 \mathrm{mV}$ (SCE) for $10 \mathrm{~min}$ and then polarized from $-1500 \mathrm{mV}$ at a rate of $0.5 \mathrm{mV} \mathrm{s}^{-1}$ in the anodic direction. In galvanostatic reduction experiments a cathodic current density of $10 \mu \mathrm{A} \mathrm{cm}^{-2}$ was applied to the electrode. Impedance measurements were carried out using a PAR Model 273 potentiostat and a Solartron/ Schlumberger FRA Model 1255. All impedance data were collected at the corrosion potential of the immersed electrodes.

\section{EXPERIMENTAL RESULTS}

Typical cathodic polarization curves recorded in $0.6 \mathrm{~mol} \mathrm{dm}^{-3} \mathrm{NaCl}$ containing 0.1 mol dm ${ }^{-3} \mathrm{Na}_{2} \mathrm{SO}_{4}$ for SS316L untreated, treated by cathodic deposition of cerium oxides/hydroxides and treatcd in boiling solutions of $0.05 \mathrm{~mol} \mathrm{dm}^{-3} \mathrm{Ce}\left(\mathrm{NO}_{3}\right)_{3}$, $0.01 \mathrm{~mol} \mathrm{dm}^{-3} \mathrm{CeCl}_{3}, 0.004 \mathrm{~mol} \mathrm{dm}^{-3} \mathrm{Ce}\left(\mathrm{CH}_{3} \mathrm{CO}_{2}\right)_{3}$ and in boiling solutions of $0.004 \mathrm{~mol} \mathrm{dm}^{-3} \mathrm{Ce}\left(\mathrm{CH}_{3} \mathrm{CO}_{2}\right)_{3}$ followed by $0.05 \mathrm{~mol} \mathrm{dm}^{-3} \mathrm{Ce}\left(\mathrm{NO}_{3}\right)_{3}$ for $60 \mathrm{~min}$ are shown in Fig. 1. It is clearly evident from a comparison of these plots that treating the SS316L electrodes in boiling solutions of cerium salts, under these conditions, provides no inhibition of the cathodic reduction reactions. Indeed, it is seen that the corrosion potential is moved significantly in the anodic direction so that cathodic currents are detected at more anodic potentials. However, an appreciable reduction in the cathodic current can be seen following the cathodic deposition of cerium oxides/hydroxides from cerium-containing solution.

The same effects can be observed from the potential-time transients shown in Fig. 2 for SS316L untreated, treated by cathodic deposition of cerium oxides/hydroxides and treated in a boiling solution of $0.05 \mathrm{~mol} \mathrm{dm}{ }^{-3} \mathrm{Ce}\left(\mathrm{NO}_{3}\right)_{3}$. These data were measured at a cathodic

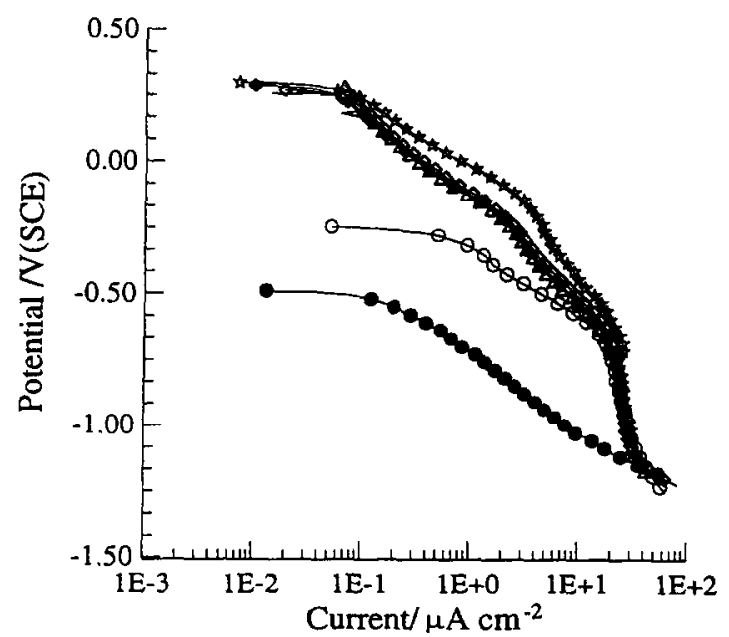

Fig. 1. Cathodic polarization plots recorded at a scan rate of $0.18 \mathrm{mV} \mathrm{s}^{-1}$ in a $0.6 \mathrm{~mol} \mathrm{dm}{ }^{-3} \mathrm{NaCl}$ and $0.1 \mathrm{~mol} \mathrm{dm}^{-3} \mathrm{Na}_{2} \mathrm{SO}_{4}$ solution for $\mathrm{SS} 316 \mathrm{~L} \bigcirc$ untreated cerium electrodeposited, 5 treated in boiling $\mathrm{Ce}\left(\mathrm{CH}_{3} \mathrm{CO}_{2}\right)_{3}, \diamond$ treated in boiling $\mathrm{Ce}\left(\mathrm{NO}_{3}\right)_{3}, \diamond$ treated in boiling $\mathrm{CeCl}_{3}$ and $\triangle$ treated in boiling $\mathrm{Ce}\left(\mathrm{CH}_{3} \mathrm{CO}_{2}\right)_{3}$ followed by boiling $\mathrm{Ce}\left(\mathrm{NO}_{3}\right)_{3}$. 


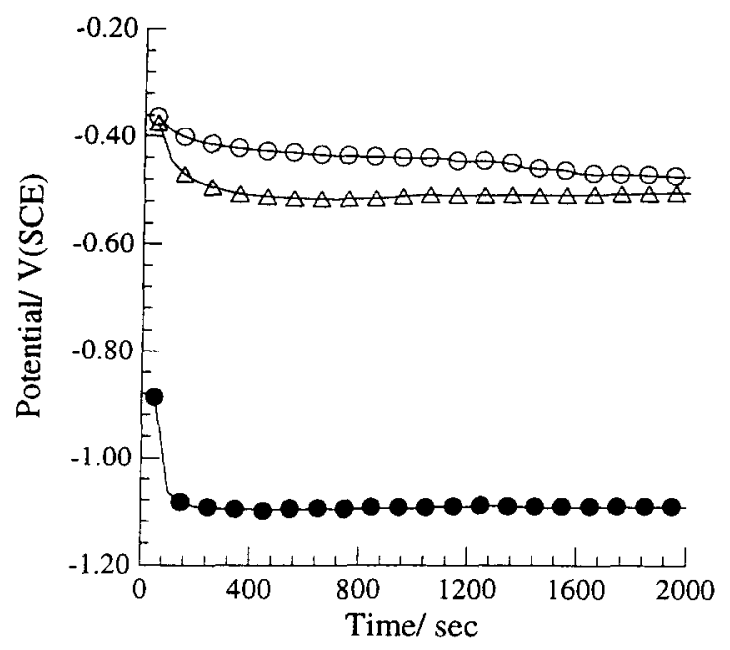

Fig. 2. Galvanostatic potential-time transients recorded at $10 \mu \mathrm{A} \mathrm{cm}^{-2}$ in a $0.6 \mathrm{~mol} \mathrm{dm}^{-3} \mathrm{NaCl}$ and $0.1 \mathrm{~mol} \mathrm{dm}^{-3} \mathrm{Na}_{2} \mathrm{SO}_{4}$ solution for SS316L $\mathrm{O}$ untreated, $\triangle$ treated in boiling $\mathrm{Ce}\left(\mathrm{NO}_{3}\right)_{3}$ and cerium electrodeposited.

current density of $10 \mu \mathrm{A} \mathrm{cm}^{-2}$ in a $0.6 \mathrm{~mol} \mathrm{dm}{ }^{-3} \mathrm{NaCl}$ solution containing $0.1 \mathrm{~mol} \mathrm{dm}^{-3}$ $\mathrm{Na}_{2} \mathrm{SO}_{4}$. Little difference between the potentials adopted by the untreated electrode and the electrode treated in the boiling $0.05 \mathrm{~mol} \mathrm{dm}{ }^{-3} \mathrm{Ce}\left(\mathrm{NO}_{3}\right)_{3}$ solution can be seen. However, the potential adopted by SS316L following the cerium deposition treatment is considerably lower reaching values in the region of $-1100 \mathrm{mV}$ (SCE) compared to that of approximately $-400 \mathrm{mV}$ (SCE) observed for the untreated electrode.

The potential-time transients measured for SS316L untreated and treated by cathodic deposition of cerium oxides/hydroxides are shown for extended periods of time in Fig. 3.

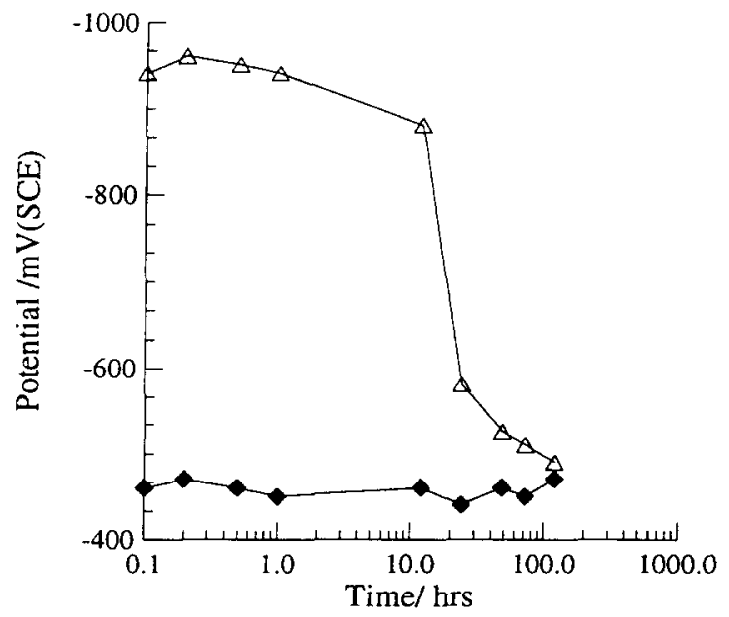

Fig. 3. Galvanostatic potential-time data recorded for extended periods of time at $10 \mu \mathrm{A} \mathrm{cm}^{-2}$ in a $0.6 \mathrm{~mol} \mathrm{dm}{ }^{-3} \mathrm{NaCl}$ and $0.1 \mathrm{~mol} \mathrm{dm}{ }^{-3} \mathrm{Na}_{2} \mathrm{SO}_{4}$ solution for $\mathrm{SS} 316 \mathrm{~L} \bullet$ untreated and $\triangle$ cerium electrodeposited. 
These data were collected by polarizing the electrodes at a cathodic current density of $10 \mu \mathrm{A} \mathrm{cm}^{-2}$ for a 10 min period at selected intervals, the electrodes being maintained under open-circuit conditions in the test solution at all other times. Here, it is seen that the cathodic inhibition effects of the electrodeposited cerium are completely lost following immersion periods of approximately $30-50 \mathrm{~h}$.

Similar cathodic behaviour was observed for SS304 and SS316 following cathodic deposition of cerium oxides/hydroxides from solution. However, the reproducibility of the cathodic polarization data following this treatment was poor. This was attributed to a much higher density of inclusions on the SS304 and SS316 electrodes than on the SS316L electrodes, as evidenced from surface analysis. On treating the SS304 and SS316 electrodes in boiling cerium salt solutions, cathodic behaviour similar to that shown in Fig. 1 was observed. However, a cathodic inhibition effect could be observed on polarizing the electrodes treated in boiling $0.05 \mathrm{~mol} \mathrm{dm}^{-3} \mathrm{Ce}\left(\mathrm{NO}_{3}\right)_{3}$ solution in the deep cathodic region prior to recording the polarization curves. Polarization data obtained in this manner are shown for SS304 and SS316 in Fig. 4. The untreated and treated electrodes were polarized at a cathodic potential of $-1500 \mathrm{mV}(\mathrm{SCE})$ for a $10 \mathrm{~min}$ period and then polarized in the anodic direction at a rate of $0.5 \mathrm{mV} \mathrm{s}^{-1}$. It can be seen from these data that the corrosion potentials of the treated electrodes lie at considerably lower potentials and that the cathodic currents for these treated electrodes are reduced by one order of magnitude, Fig. 4.

It was possible also to observe an inhibition of the cathodic reactions on polarizing the electrodes at cathodic potentials in cerium-containing solutions. Typical current-time plots obtained for SS304 and SS316 polarized at $-700 \mathrm{mV}$ (SCE) in $0.1 \mathrm{~mol} \mathrm{dm}^{-3} \mathrm{NaCl}$ solution and in $0.1 \mathrm{~mol} \mathrm{dm}^{-3} \mathrm{NaCl}$ solution containing $0.05 \mathrm{~mol} \mathrm{dm}^{-3} \mathrm{Ce}\left(\mathrm{NO}_{3}\right)_{3}$ solution (both solutions being adjusted to the same $\mathrm{pH}$ of 3.7) are shown in Fig. 5(a) and (b), respectively. The cathodic current is reduced by a factor of two on addition of the cerium-containing solution for both SS304 and SS316. These data are consistent with the deposition of cerium oxides/hydroxides onto the electrode surfaces and the subsequent inhibition of the cathodic reduction reactions by the deposited cerium.

Typical anodic polarization curves recorded in $0.6 \mathrm{~mol} \mathrm{dm}^{-3} \mathrm{NaCl}$ containing $0.1 \mathrm{~mol} \mathrm{dm}{ }^{-3} \mathrm{Na}_{2} \mathrm{SO}_{4}$ for $\mathrm{SS} 316 \mathrm{~L}$ untreated, treated by cathodic deposition of cerium oxides/hydroxides and treated in boiling solutions of $0.05 \mathrm{~mol} \mathrm{dm}^{-3} \mathrm{Ce}\left(\mathrm{NO}_{3}\right)_{3}$, $0.01 \mathrm{~mol} \mathrm{dm}^{-3} \mathrm{CeCl}_{3}, 0.004 \mathrm{~mol} \mathrm{dm}^{-3} \mathrm{Ce}\left(\mathrm{CH}_{3} \mathrm{CO}_{2}\right)_{3}$ and in boiling solutions of $0.004 \mathrm{~mol} \mathrm{dm}^{-3} \mathrm{Ce}\left(\mathrm{CH}_{3} \mathrm{CO}_{2}\right)_{3}$ followed by $0.05 \mathrm{~mol} \mathrm{dm}^{-3} \mathrm{Ce}\left(\mathrm{NO}_{3}\right)_{3}$ and in boiling solutions of $0.01 \mathrm{~mol} \mathrm{dm}^{-3} \mathrm{CeCl}_{3}$ followed by $0.05 \mathrm{~mol} \mathrm{dm}^{-3} \mathrm{Ce}\left(\mathrm{NO}_{3}\right)_{3}$ are shown in Fig. 6. Treatment in the boiling cerium salt solutions has modified considerably the anodic polarization behaviour of SS316L. A lower passive current density is measured, a much higher corrosion potential is observed and increases in the pitting potentials by about 50 $100 \mathrm{mV}$ are observed. However, the anodic polarization behaviour of the untreated electrode and the electrode treated by the cathodic deposition of cerium oxides/hydroxides are similar.

An even greater increase in the pitting potential of SS304 and SS316 could be observed following treatment in boiling cerium salt solutions. Representative anodic polarization plots recorded in $0.6 \mathrm{~mol} \mathrm{dm}^{-3} \mathrm{NaCl}$ and $0.1 \mathrm{~mol} \mathrm{dm}^{-3} \mathrm{Na}_{2} \mathrm{SO}_{4}$ solution for SS304 untreated, treated in boiling $0.05 \mathrm{~mol} \mathrm{dm}^{-3} \mathrm{Ce}\left(\mathrm{NO}_{3}\right)_{3}$, treated in boiling $0.01 \mathrm{~mol} \mathrm{dm}^{-3}$ $\mathrm{CeCl}_{3}$ followed by $0.05 \mathrm{~mol} \mathrm{dm}^{-3} \mathrm{Ce}\left(\mathrm{NO}_{3}\right)_{3}$ and treated in boiling $0.004 \mathrm{~mol} \mathrm{dm}^{-3}$ $\mathrm{Ce}\left(\mathrm{CH}_{3} \mathrm{CO}_{2}\right)_{3}$ followed by $0.05 \mathrm{~mol} \mathrm{dm}{ }^{-3} \mathrm{Ce}\left(\mathrm{NO}_{3}\right)_{3}$ are shown in Fig. 7. A reduction in the passive current density and an increase in the corrosion potential are observed for the 

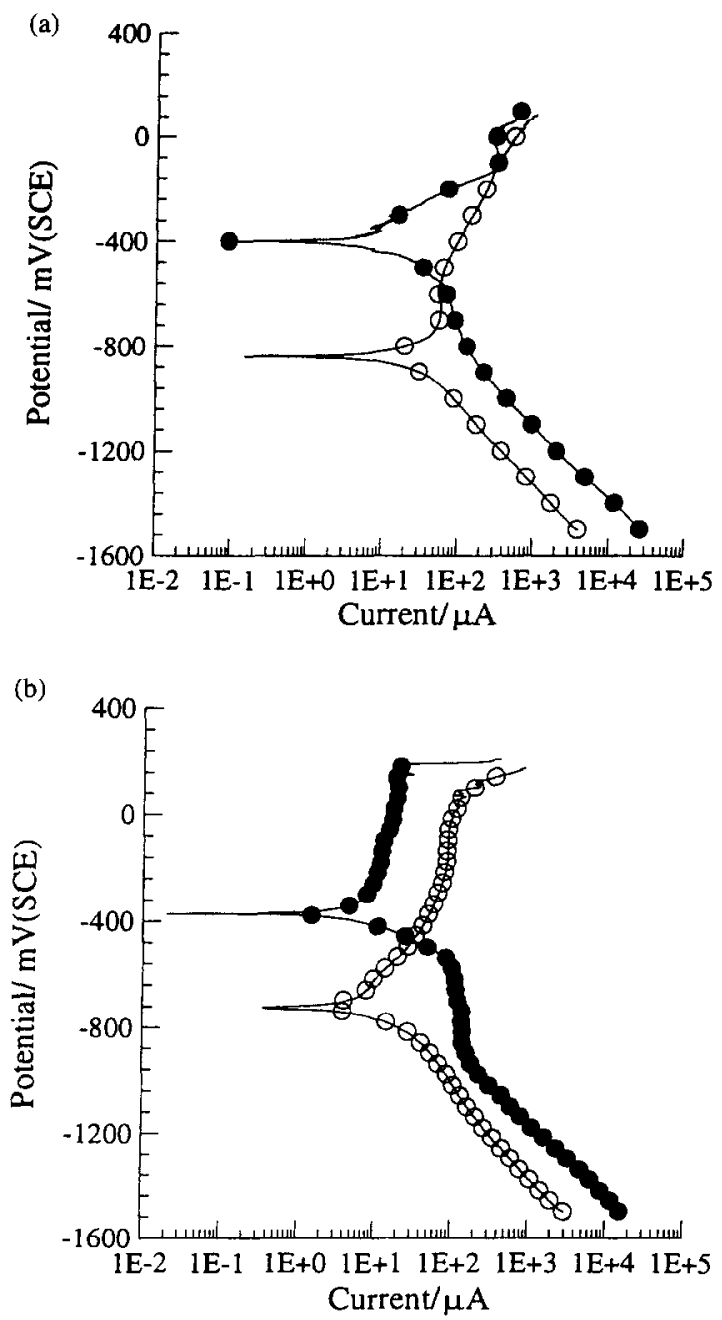

Fig. 4. (a) Polarization plots recorded in a $0.6 \mathrm{~mol} \mathrm{dm}^{-3} \mathrm{NaCl}$ and $0.1 \mathrm{~mol} \mathrm{dm}{ }^{-3} \mathrm{Nu}_{2} \mathrm{SO}_{4}$ solution at a scan rate of $0.5 \mathrm{mV} \mathrm{s}^{-1}$ following a 10 min cathodic polarization period at $-1500 \mathrm{mV}$ (SCE) for SS304 untreated and $O$ treated in boiling $\mathrm{Ce}\left(\mathrm{NO}_{3}\right)_{3}$ solution.(b) Polarization plots recorded in a $0.6 \mathrm{~mol} \mathrm{dm}{ }^{-3} \mathrm{NaCl}$ and $0.1 \mathrm{~mol} \mathrm{dm}{ }^{-3} \mathrm{Na}_{2} \mathrm{SO}_{4}$ solution at a scan rate of $0.5 \mathrm{mV} \mathrm{s}^{-1}$ following a 10 min cathodic polarization period at $-1500 \mathrm{mV}(\mathrm{SCE})$ for $\mathrm{SS} 316-$ untreated and $O$ treated in boiling $\mathrm{Ce}\left(\mathrm{NO}_{3}\right)_{3}$ solution.

treated electrodes, but a much greater increase in the pitting potentials occurred, exceeding $200 \mathrm{mV}$ in some cases.

Anodic polarization plots recorded for SS304 under the same conditions, untreated and treated in $0.15 \mathrm{~mol} \mathrm{dm}{ }^{-3} \mathrm{NaNO}_{3}$ solution and treated in $0.03 \mathrm{~mol} \mathrm{dm}{ }^{-3} \mathrm{NaCl}$ followed by 0.15 mol dm ${ }^{-3} \mathrm{NaNO}_{3}$ are shown in Fig. 8. Here, a significant increase in the pilling potential, exceeding $200 \mathrm{mV}$, is observed following the chloride/nitrate treatment. This result seems to be associated with the dissolution and removal of some surface inclusions during the chloride treatment and passivation of the system during the nitrate treatment, as 

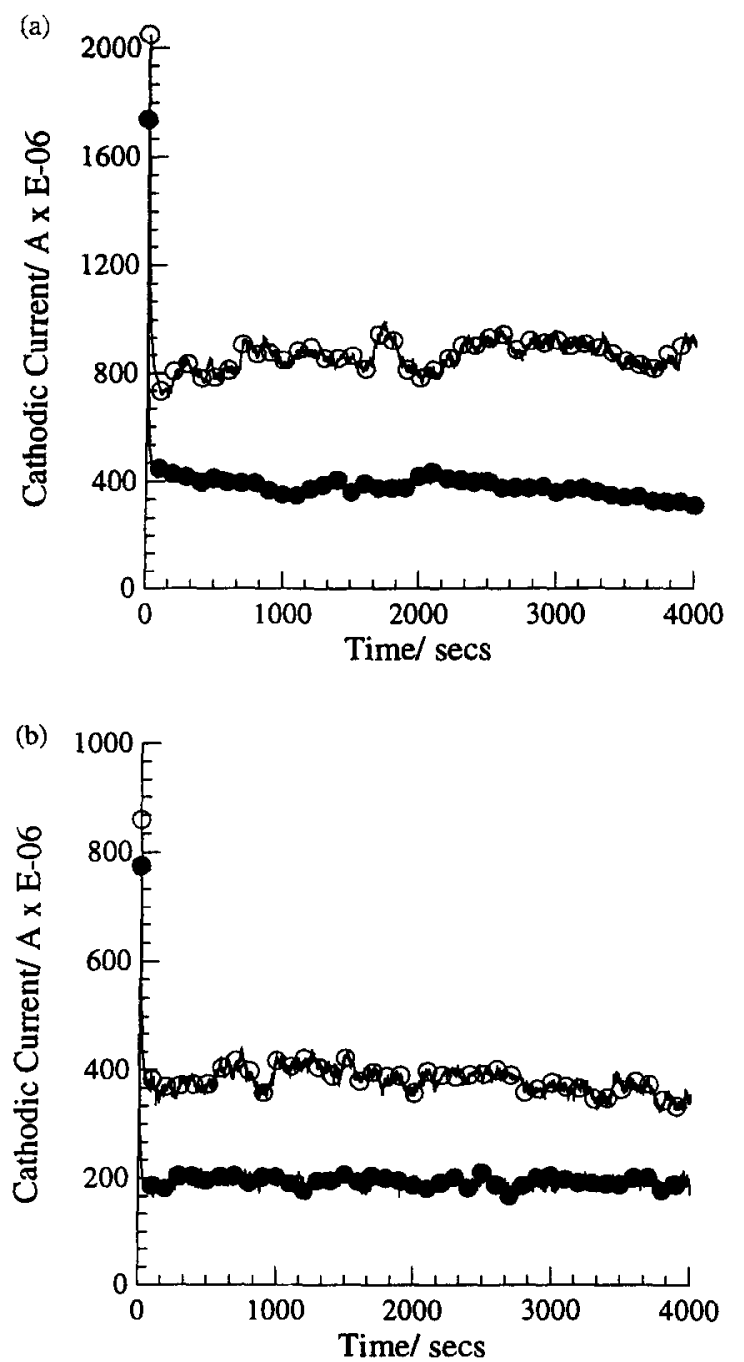

Fig. 5. (a): Cathodic-current time transients recorded for SS304 polarized at $-700 \mathrm{mV}(\mathrm{SCE})$ in $O$ a $0.5 \mathrm{~mol} \mathrm{dm}{ }^{-3} \mathrm{NaCl}$ solution and a $0.5 \mathrm{~mol} \mathrm{dm}^{-3} \mathrm{NaCl}$ solution containing $0.05 \mathrm{~mol} \mathrm{dm}^{-3}$ $\mathrm{Ce}\left(\mathrm{NO}_{3}\right)_{3}(\mathrm{~b})$ : Cathodic-current time transients recorded for SS316 polarized at $-700 \mathrm{mV}(\mathrm{SCE})$ in $\mathrm{O}$ a $0.5 \mathrm{~mol} \mathrm{dm}{ }^{-3} \mathrm{NaCl}$ solution and $0.5 \mathrm{~mol} \mathrm{dm}{ }^{-3} \mathrm{NaCl}$ solution containing $0.05 \mathrm{~mol} \mathrm{dm}^{-3}$ $\mathrm{Ce}\left(\mathrm{NO}_{3}\right)_{3}$.

small pit-like areas could be observed on the surface following the chloride treatment. Indeed, SEM examination of the SS304 electrode treated in boiling $0.004 \mathrm{~mol} \mathrm{dm}^{-3}$ $\mathrm{Ce}\left(\mathrm{CH}_{3} \mathrm{CO}_{2}\right)_{3}$ solution revealed a number of shallow holes, Fig. 9(a). EDAX analysis indicated the presence of sulfur and cerium in these holes, Fig. 9(b). Cerium was detected in large quantities only in these holes from which Mn had been removed presumably by the boiling treatment in the acetate solution. Thus, the subsequent apparent increase in the pitting potential may arise as a result of a lower population of $\mathrm{MnS}$ pit nucleation sites. 


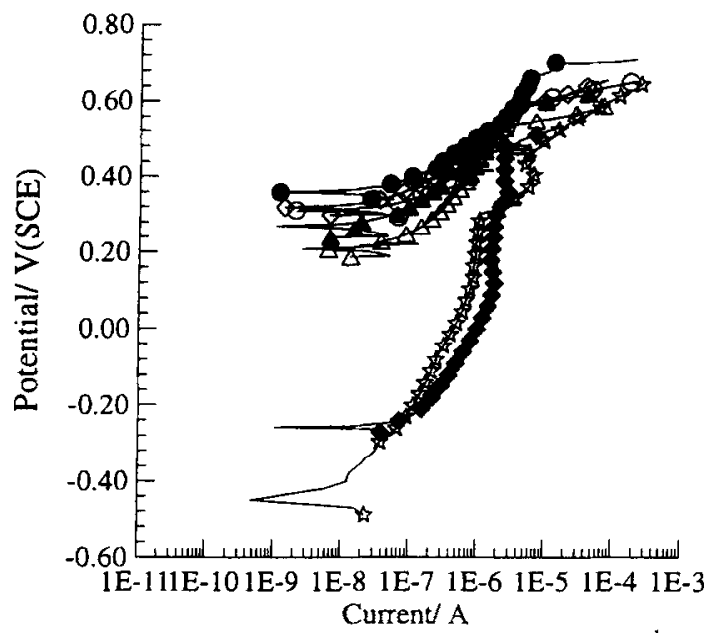

Fig. 6. Anodic polarization plots recorded at a scan rate of $0.18 \mathrm{mV} \mathrm{s}^{-1}$ in a $0.6 \mathrm{~mol} \mathrm{dm} \mathrm{m}^{-3} \mathrm{NaCl}$ and $0.1 \mathrm{~mol} \mathrm{dm}{ }^{-3} \mathrm{Na}_{2} \mathrm{SO}_{4}$ solution for $\mathrm{SS} 316 \mathrm{~L} \bullet$ untreated, cerium electrodeposited, $\bigcirc$ treated in boiling $\mathrm{Ce}\left(\mathrm{CH}_{3} \mathrm{CO}_{2}\right)_{3}, \diamond$ treated in boiling $\mathrm{Ce}\left(\mathrm{NO}_{3}\right)_{3}, \triangle$ treated in boiling $\mathrm{CeCl}_{3},-$ treated in boiling $\mathrm{Ce}\left(\mathrm{CH}_{3} \mathrm{CO}_{2}\right)_{3}$ followed by boiling $\mathrm{Ce}\left(\mathrm{NO}_{3}\right)_{3}$ and $\Delta$ treated in boiling $\mathrm{CeCl}_{3}$ followed by boiling $\mathrm{Ce}\left(\mathrm{NO}_{3}\right)_{3}$

Impedance data obtained for SS316L untreated, treated by cathodic polarization in cerium-containing solution, treated in a boiling $0.05 \mathrm{~mol} \mathrm{dm}^{-3} \mathrm{Ce}\left(\mathrm{NO}_{3}\right)_{3}$ solution and treated in a $0.15 \mathrm{~mol} \mathrm{dm}^{-3} \mathrm{NaNO}_{3}$ solution are shown in Fig. 10. The impedance spectra obtained for the untreated electrode and the electrode treated by the cathodic deposition of cerium oxides/hydroxides appear similar. Calculated polarization resistance, $R_{\mathrm{p}}$, values

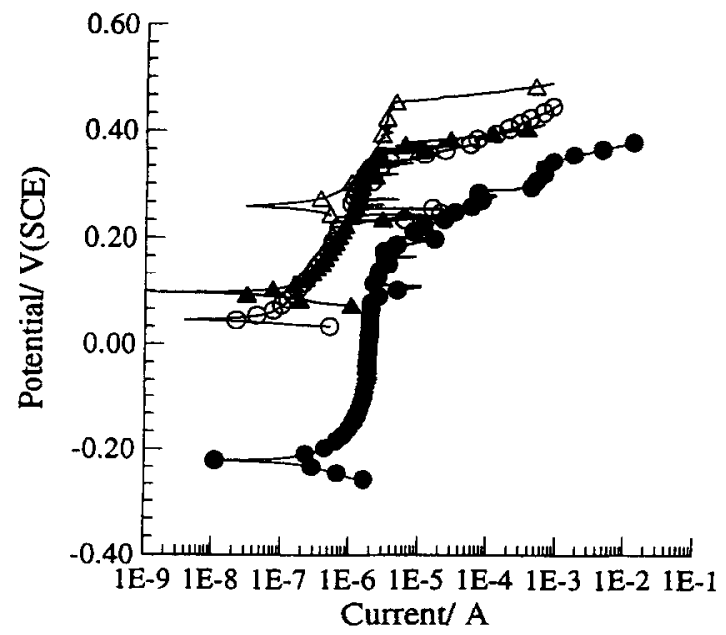

Fig. 7. Anodic polarization plots recorded in $0.6 \mathrm{~mol} \mathrm{dm}^{-3} \mathrm{NaCl}$ and $0.1 \mathrm{~mol} \mathrm{dm}{ }^{-3} \mathrm{Na}_{2} \mathrm{SO}_{4}$ solution for $\mathrm{SS} 304-$ untreated; $O$ treated in boiling $\mathrm{Ce}\left(\mathrm{NO}_{3}\right)_{3}, \triangle$ treated in boiling $\mathrm{CeCl}_{3}$ followed by boiling $\mathrm{Ce}\left(\mathrm{NO}_{3}\right)_{3}$ and $\Delta$ treated in boiling $\mathrm{Ce}\left(\mathrm{CH}_{3} \mathrm{CO}_{2}\right)_{3}$ followed by boiling $\mathrm{Ce}\left(\mathrm{NO}_{3}\right)_{3}$. 


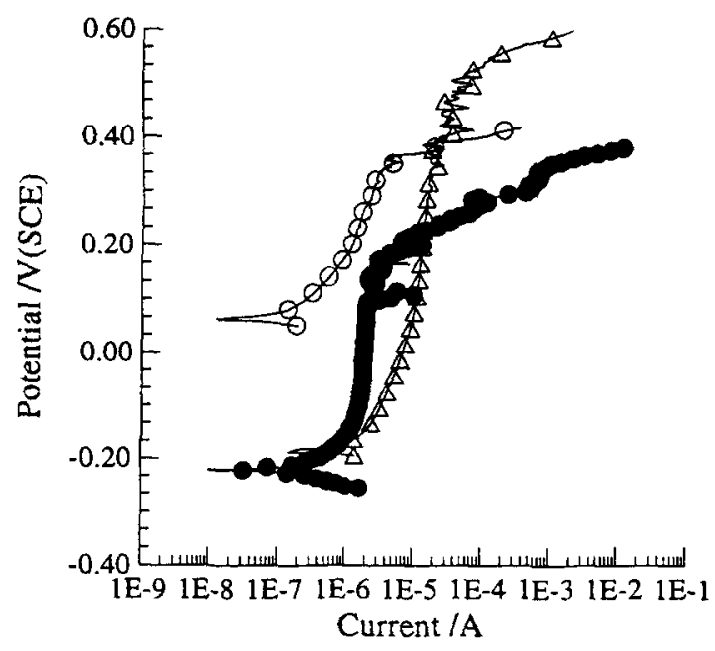

Fig. 8. Anodic polarization plots recorded in $0.6 \mathrm{~mol} \mathrm{dm}{ }^{-3} \mathrm{NaCl}$ and $0.1 \mathrm{~mol} \mathrm{dm}{ }^{-3} \mathrm{Na}_{2} \mathrm{SO}_{4}$ solution for SS304 untreated, $\bigcirc$ treated in boiling $\mathrm{NaNO}_{3}$ and $\triangle$ treated in boiling $\mathrm{NaCl}$ followed by boiling $\mathrm{NaNO}_{3}$.

were between 0.2 and $0.3 \mathrm{M} \Omega \mathrm{cm}^{2}$ for these two samples. A significant increase in $R_{\mathrm{p}}$ can be observed following treatment in the boiling $\mathrm{NaNO}_{3}$ and boiling $\mathrm{Ce}\left(\mathrm{NO}_{3}\right)_{3}$ solutions, with $R_{\mathrm{p}}$ increasing to values between 5 and $7 \mathrm{M} \Omega \mathrm{cm}^{2}$ for the samples treated in boiling solutions. These observed improvements in the passive film properties are consistent with the lower passive current densities and the increase in the pitting potentials observed in Figs 7 and 8 .

\section{DISCUSSION}

The experimental results presented in this communication show that some cathodic polarization step is required, following treatment of the stainless steel electrodes in boiling solutions of cerium salts, in order to render the deposited cerium effective in inhibiting the rate of the oxygen reduction reaction. If the clcctrodes are simply treated in the boiling cerium salt solutions, no decrease in the rate of the oxygen reduction reaction is observed, Figs 1 and 4. But, if the electrodes are polarised in the deep cathodic region, following the boiling treatment, or if the electrodes are polarized under cathodic conditions in ceriumcontaining solutions, then a decrease in the rate of the oxygen reduction reaction is observed, Figs 1-5. The observed decreases in the rate of the oxygen reduction reaction are somewhat less than those reported by Lu and Ives, ${ }^{14-16}$ but this may be due to the fact that the solutions used by Lu and Ives were saturated with dissolved oxygen and all experiments were performed with rotating disk electrodes. In particular, the presence of a much higher surface concentration of dissolved oxygen during the cathodic polarization step used by $\mathrm{Lu}$ and Ives may lead to more efficient formation of hydroxides of cerium on the surface.

Polarization of the electrodes under these cathodic conditions should lead to the reduction of metal oxides on the surface, however cerium (III) oxides/hydroxides should remain stable. This is seen from the electrode potential of $-2.37 \mathrm{~V}(\mathrm{SHE})$ calculated at a $\mathrm{pH}$ of 10.0 for the reduction reaction, 

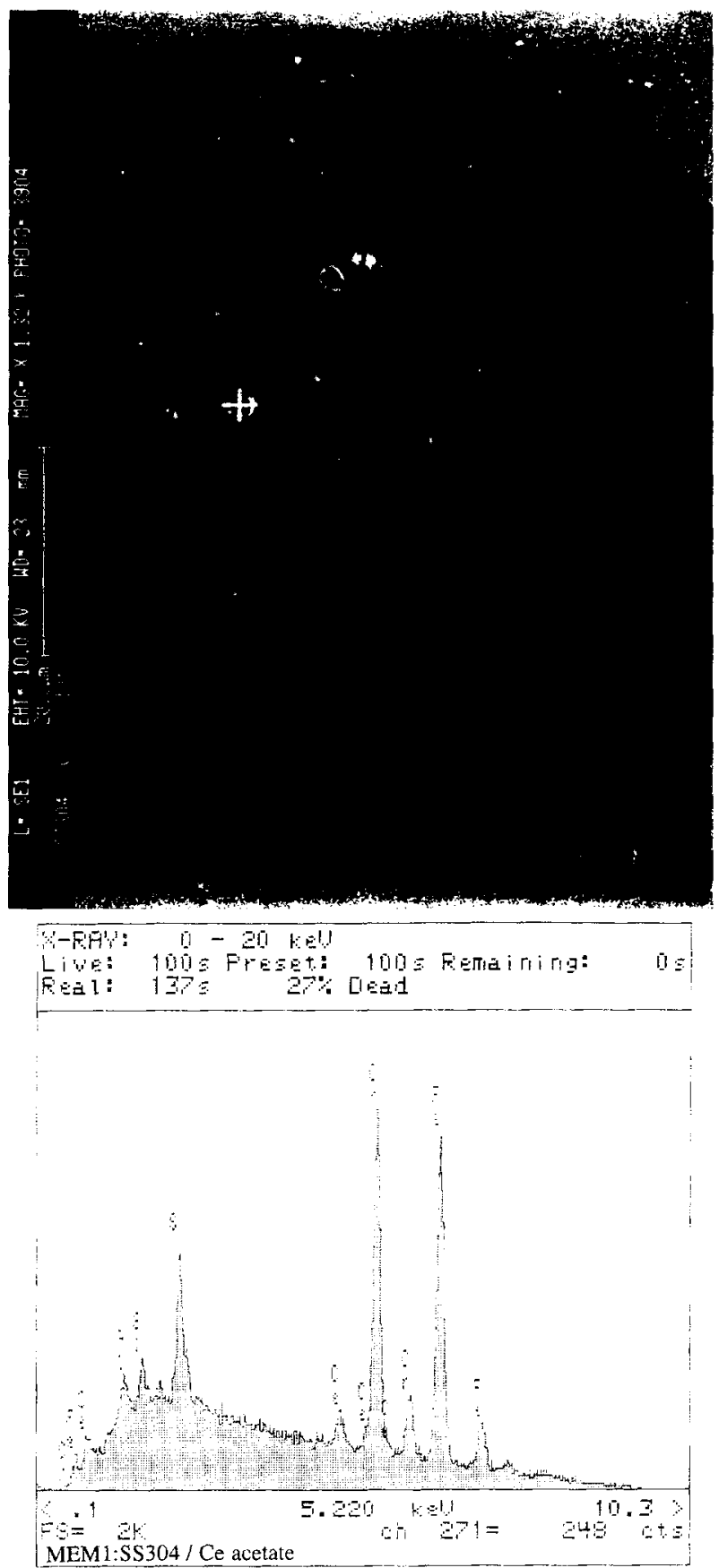

Fig. 9. (a) SEM micrograph of SS304 after treatment in boiling $\mathrm{Ce}\left(\mathrm{CH}_{3} \mathrm{CO}_{2}\right)_{3}$, (b) EDAX analysis of hole identified in (a). 

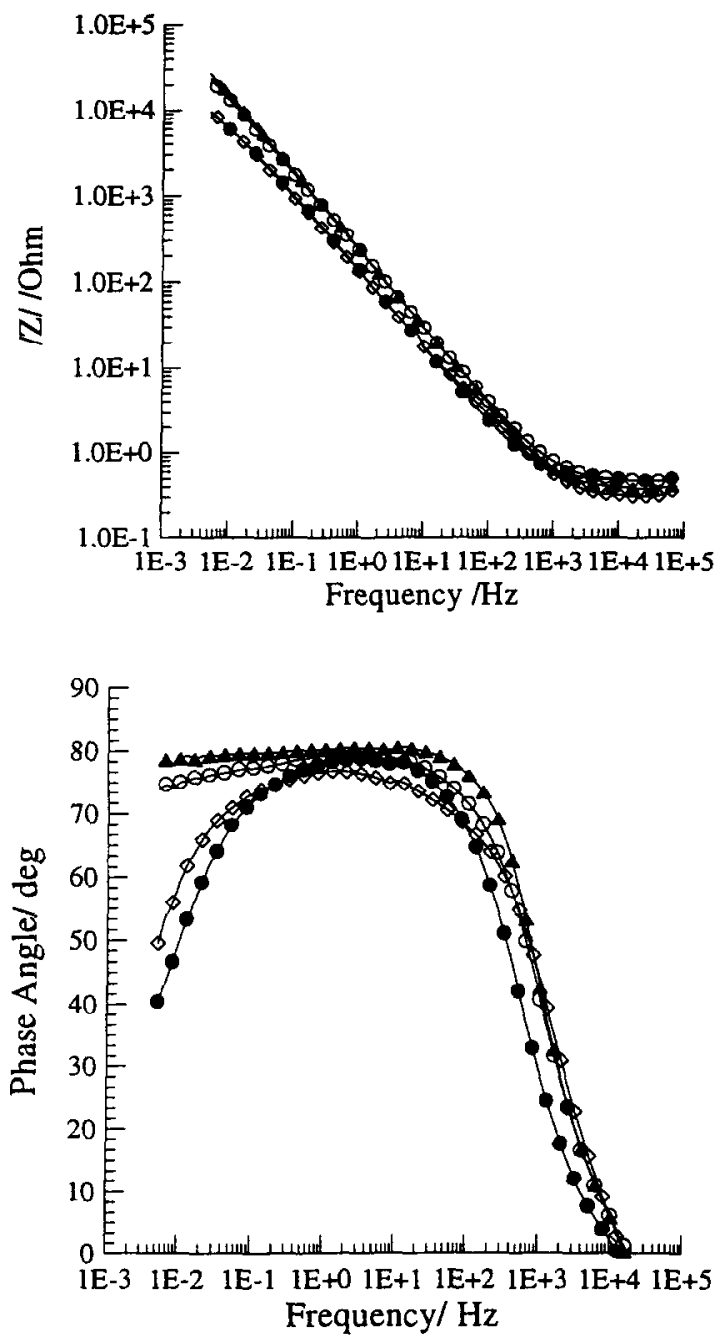

Fig. 10. Impedance data recorded in $0.6 \mathrm{~mol} \mathrm{dm}{ }^{-3} \mathrm{NaCl}$ and $0.1 \mathrm{~mol} \mathrm{dm}{ }^{-3} \mathrm{Na}_{2} \mathrm{SO}_{4}$ solution for SS316L untreated, $\Delta$ treated in boiling $\mathrm{Ce}\left(\mathrm{NO}_{3}\right)_{3}, \diamond$ treated by cerium electrodeposition and $O$ treated in boiling $\mathrm{NaNO}_{3}$ solution.

$$
\mathrm{Ce}_{2} \mathrm{O}_{3}+6 \mathrm{H}^{+}+6 \mathrm{e}^{-} \rightarrow 2 \mathrm{Ce}+3 \mathrm{H}_{2} \mathrm{O}
$$

this potential being significantly more cathodic than the potentials used in these experiments. However, this cathodic procedure should favour the reduction of $\mathrm{Ce}(\mathrm{IV})$ to $\mathrm{Ce}$ (III) oxides or hydroxides. It is likely that cerium incorporated at the surface during the boiling treatments resides in predominantly the (IV) oxidation state with a smaller amount residing in the (III) oxidation state. For example, Aldykiewiez et al. ${ }^{14}$ have suggested that the first step involved in the formation of a cerium-rich film is the oxidation of cerium (III) to (IV) in solution, this being favoured by either oxygen or hydrogen peroxide dissolved in solution. Insoluble $\mathrm{CeO}_{2}$ is then precipitated at the electrode surface at regions where cathodic reactions give rise to a local increase in the $\mathrm{pH}$ of the solution adjacent to the 
electrode surface. The presence of the oxidizing nitrate anion and dissolved oxygen in the treatment solutions used in this study and by Lu and Ives should favour the oxidation of $\mathrm{Ce}(\mathrm{III})$ to $\mathrm{Ce}$ (IV), so that it is likely that most of the cerium in the precipitated cerium oxides/hydroxides will exist in the (IV) oxidation state. If indeed this cathodic polarisation treatment leads to reduction of the cerium(IV) hydroxides to cerium(III) hydroxides, then it appears that these cerium(III) hydroxide species are responsible for the inhibition of the oxygen reduction reaction. Alternatively, the generation of alkaline regions at the electrode surface during the cathodic polarisation step may lead to the formation of hydrated cerium hydroxides that are more efficient in the retardation of any subsequent oxygen reduction reaction. This is consistent with the results of Lu and Ives, where a significant decrease in the rate of the oxygen reduction reaction was observed following cathodic polarization in a saturated oxygen solution. This cathodic inhibition effect begins to weaken after approximately a $1 \mathrm{~h}$ immersion period in a neutral non-cerium containing solution, and disappcars almost completely following a $30 \mathrm{~h}$ immersion period, Fig. 3. This result is considered to be due to the gradual dissolution of cerium from the electrode surface.

A reduction in the passive current density and an ennoblement in the pitting potential were observed following the boiling treatments in cerium salt solutions, Higs 6 and 7. The maximum shift in the pitting potential observed under these conditions was of the order of $200 \mathrm{mV}$, considerably lower than the $800 \mathrm{mV}$ ennoblement observed by Lu and Ives. ${ }^{14}$ The reasons for these considerable variations in the two sets of data are unclear. However, cerium oxides/hydroxides deposited at room temperature seem to have little effect on the anodic behaviour of the electrodes, Fig. 6, suggesting that the boiling treatments give rise to the observed passivation effects. It seems that the nitrate species are responsible for the enhanced passivation effects as a 10 -fold increase in the polarization resistance is observed following immersion of the electrodes in boiling $\mathrm{NaNO}_{3}$ solutions, Fig. 10. Indeed, the nitrate species may lead to an enrichment of chromium in the passive film which is consistent with the XPS data obtained by Lu and Ives. ${ }^{15}$

On comparing the data presented in Figs 7 and 8 it is seen that the most noble pitting potentials are recorded for the electrodes immersed in boiling solutions of $\mathrm{NaCl}$ followed by $\mathrm{NaNO}_{3}$. This apparent increase in the pitting resistance seems to be associated with pitting attack of the electrodes in the boiling $\mathrm{NaCl}$ solutions (or acetate solutions, Fig. 9), this surface attack removing many of the pit nucleation sites, as pits seldom nucleate at preattacked sites. ${ }^{17}$ The electrodes are then passivated in the nitrate solution, so that on subsequent polarization more passive behaviour is observed. Similar effects occur in the acidified cerium salt solutions, with the chloride, nitrate or acetate species promoting dissolution of potential pit nucleation sites. However, it seems that the deposited cerium oxides/hydroxides do not inhibit the onset of pitting attack.

\section{CONCLUSIONS}

Treatment of SS304, SS316 and SS316L electrodes by immersion in cerium-containing solutions at elevated temperatures has little effect in inhibiting the oxygen reduction reaction. However, if the treated electrodes are polarized in the deep cathodic region or if untreated electrodes are polarized under cathodic conditions in cerium-containing solutions then a significant reduction in the rate of the oxygen reduction reaction is observed. This result seems to suggest that the nature, or oxidation state, of the cerium oxides/hydroxides is important in inhibiting the cathodic reactions. 
The presence of cerium oxides/hydroxides on the surface of the stainless steel electrodes had little effect on the anodic polarization behaviour. The observed increase in the pitting potential, $(50-200 \mathrm{mV})$ following treatment of the electrodes in boiling cerium salt solutions was attributed to the removal of $\mathrm{MnS}$ inclusions leading to a surface with a lower population of pit nucleation sites. The reduction in the passive current following the boiling treatments was attributed to passivation by the nitrate component of the solution.

Acknowledgements-This project was supported by the NATO Collaborative Research Grants Programme (Grant No. CRG 950593).

\section{REFERENCES}

1. P. Marcus, B. Baroux and M. Keddam, Editors, proc. Modifications of Passive Films, Paris, France, Feb. 1993, European Federation of Corrosion Publ. No. 12, The Institute of Metals, London, (1994).

2. B.P.F. Goldie and J.J. McCarroll, Australian Patent, AU-32947/84, (1984).

3. D.R. Arnott, N.E. Ryan, B.R.W. Hinton, B.A. Sexton and A.E. Hughes, Appl. Surf. Sci. 23,236 (1985).

4. D.R. Arnott, B.R.W. Hinton and N.E. Ryan, Corrosion 45, 12 (1989).

5. B.R.W. Hinton, D.R. Arnott and N.E. Ryan, Materials Forum 9, 162 (1986).

6. R.B.W. Hinton, $J$. of Alloys and Compounds 180, 15 (1992).

7. F. Mansfeld and Y. Wang, Br. Corros. J. 29, 194 (1994).

8. F. Mansfeld and Y. Wang, Materials Science and Engineering A198, 51 (1995).

9. F. Mansfeld, Y. Wang and H. Shih, J. Electrochem. Soc. 138, L74 (1991).

10. A.J. Davenport, H.S. Isaacs and M.W. Kendig, Corros. Sci. 32, 653 (1991).

11. A.J. Aldekiewicz, A.J. Davenport and H.S. Isaacs, J. Electrochem. Soc. 143, 147 (1996).

12. A.J. Aldekiewicz, H.S. Isaacs and A.J. Davenport, J. Electrochem Soc, 142, 3342 (1995).

13. Y.C. Lu and M.B. Ives, Corros. Sci. 34, 1773 (1993).

14. Y.C. Lu and M.B. Ives, Corros. Sci. 37, 145 (1995).

15. Y.C. Lu, M.B. Ives, G.I. Sproule and M.J. Graham, Proc. H.H. Uhlig Memorial Symp., The Electrochemical Soc., Proc. Vol. 94-26, 151, (1994).

16. Y.C. Lu. and M.B. Ives, Proc. Critical Factors in Localized Corrosion $I I$., The Electrochemical Soc., Proc. Vol. 95-15, 253, (1995).

17. J. Stewart and D.E. Williams, Corros. Sci. 33, 457 (1992). 